Article

\title{
The effect of $\mathrm{Pd}$ precursor on $\mathrm{Pd} / \mathrm{Ce}_{0.67} \mathrm{Zr}_{0.33} \mathrm{O}_{2}$ catalysts for automotive emission control
}

\author{
Siyu Lin, Linyan Yang, Xue Yang, Renxian Zhou* \\ Institute of Catalysis, Zhejiang University, Hangzhou 310028, Zhejiang, China
}

\section{A R T I C L E I N F O}

Article history:

Received 29 October 2014

Accepted 12 December 2014

Published 20 April 2015

\section{Keywords:}

Palladium precursor

Three-way catalyst

Noble metal-support interaction

Light-off catalytic performance

\begin{abstract}
A B S T R A C T
A Pd/CZ(NO) catalyst prepared with $\mathrm{Pd}\left(\mathrm{NO}_{3}\right)_{2}$ as the metal precursor exhibited the best catalytic performance for $\mathrm{HC}$ and $\mathrm{CO}$ elimination because of a higher oxygen storage capacity, abundant small $\mathrm{Pd}_{n}$ clusters and a strong Pd-support interaction that facilitated electron transfer from $\mathrm{PdO}_{x}$ particles to the $\mathrm{CZ}$ support. A Pd/CZ(NH) catalyst prepared with $\mathrm{Pd}\left(\mathrm{NH}_{3}\right)_{4}\left(\mathrm{NO}_{3}\right)_{2}$ as the metal precursor exhibited good performance for $\mathrm{NO}$ and $\mathrm{NO}_{2}$ elimination due to a higher Pd dispersion, abundant bigger $\mathrm{Pd}_{n}$ clusters and oxidized/metallic Pd coexistence. A Pd/CZ(Cl) catalyst prepared with $\mathrm{H}_{2} \mathrm{PdCl}_{4}$ as the metal precursor exhibited low catalytic activity due to a low Pd dispersion, weak Pd-support interaction, and the trace amount of $\mathrm{CeOCl}$ which inhibited oxygen vacancy creation. However, it showed good thermal stability, and benefited when an aging treatment removed the residual chlorine species and also promoted the interaction between $\mathrm{PdO}_{x}$ and the support.
\end{abstract}

(C) 2015, Dalian Institute of Chemical Physics, Chinese Academy of Sciences. Published by Elsevier B.V. All rights reserved.

\section{Introduction}

Three-way catalysts (TWCs) are extensively used to diminish pollutant emissions from gasoline automotives. The classical components of these systems are $\mathrm{Rh}, \mathrm{Pt}$, and $\mathrm{Pd}$ as active metals and Ce-Zr mixed oxide as promoter. The use of $\mathrm{Pd}$ as a single active metal in TWCs has recently gained increasing attention due to the high cost and scarcity of Rh and its high activity for oxidation reactions [1-5]. Since the simultaneous conversions of $\mathrm{HC}, \mathrm{CO}$, and $\mathrm{NO}_{x}$ are strongly affected by the oxygen partial pressure, $\mathrm{Ce}-\mathrm{Zr}$ mixed oxides with an inherent property to release or adsorb oxygen have been widely used. Ceria is recognized as the chief oxygen storage material because of its facile redox cycling through the $\mathrm{Ce}^{3+} / \mathrm{Ce}^{4+}$ cycle. It also has the ability to increase the thermal and structural stability of the catalyst carrier [6]. The introduction of zirconia into the ceria lattice can significantly increase the oxygen va- cancies in the fluorite lattice by charge compensation, facilitate oxygen diffusion or transport and enhance the thermal stability of the solid solution [7]. Better results are obtained with $\mathrm{Ce}_{x} \mathrm{Zr}_{1-x} \mathrm{O}_{2}$ with $x$ ranging from 0.6 to $0.8[8,9]$. It is well known that several factors influence the catalytic performance of supported Pd catalysts, such as the nature of the support, physicochemical properties of the metal particles, and metal-support interaction $[1,3,10]$. Among these factors, the configuration of the noble metal particles and noble metal-support interaction are considered to be two important factors affecting the amount and nature of the active sites [11]. Wang et al. [12,13] reported the effect of rare earth element ( $\mathrm{La}, \mathrm{Nd}, \mathrm{Pr}, \mathrm{Sm}$ and $\mathrm{Y}$ ) doping on the three-way catalytic performance of $\mathrm{Pd} / \mathrm{Ce}_{x} \mathrm{Zr}_{1-\mathrm{x}} \mathrm{O}_{2}$ catalyst and showed that the addition of La or Pr promoted the interaction between $\mathrm{PdO}_{x}$ species and $\mathrm{Ce}_{x} \mathrm{Zr}_{1-x} \mathrm{O}_{2}$, resulting in increased thermal stability and oxygen storage capacity (OSC). In addition, we have studied the effects of $\mathrm{CeO}_{2}-\mathrm{ZrO}_{2}$ presence

\footnotetext{
* Corresponding author. Tel: +86-571-88273290; Fax: +86-571-88273283; E-mail: zhourenxian@zju.edu.cn This work was supported by the National High Technology Research and Development Program of China (863 Program, 2011AA03A406) and Zhejiang Leading Team of Science and Technology Innovation (2009R50020). 
in $\mathrm{Pd} / \mathrm{Al}_{2} \mathrm{O}_{3}$ catalysts on the redox behavior of $\mathrm{PdO}_{x}$ and their combustion activity [14]. The interaction between Ce-Zr and $\mathrm{PdO}_{x}$ controlled the growth of $\mathrm{PdO}_{x}$ particles and inhibited the decomposition of $\mathrm{PdO}$ to $\mathrm{Pd}^{0}$, and the reoxidation ability of $\mathrm{Pd}^{0}$ to $\mathrm{PdO}$ was greatly improved. Therefore, it increased thermal stability and the catalytic performance of the $\mathrm{Pd} / \mathrm{Ce}-\mathrm{Zr} / \mathrm{Al}_{2} \mathrm{O}_{3}$ catalyst for methane combustion. Owing to the complexity of the large number of chemical reactions of TWCs, some arguments exist with regard to both the best configuration of the noble metal particle and the noble metal-support interaction.

The nature of the noble metal precursor utilized in the preparation of the catalyst is also considered to affect the noble metal-support interaction. Baylet et al. [15] studied the influence of the Pd precursor on the activity for $\mathrm{CH}_{4}$ combustion and reported that using $\mathrm{Pd}(\mathrm{acac})_{2}$ as the metal precursor gave a higher dispersion ( $>30 \%)$, smaller Pd particle size $(<3 \mathrm{~nm})$ and better catalytic performance than when using $\mathrm{Pd}\left(\mathrm{NO}_{3}\right)_{2}$. Panprant et al. [16] investigated the effects of the Pd precursor on hydrogenation and reported that using $\mathrm{PdCl}_{2}$ as a precursor led to smaller Pd particles $(<4.5 \mathrm{~nm}$ ), higher dispersion (> $26 \%$ ) and hydrogenation activity than the catalysts prepared with $\mathrm{Pd}\left(\mathrm{NO}_{3}\right)_{2}$ or $\mathrm{Pd}\left(\mathrm{OOCCH}_{3}\right)_{2}$ precursors. However, the mechanism and the interaction between Pd precursor and the support are still not clear, and need to be further studied. On the other hand, for different reactions, the configuration of the noble metal particle and the different interaction between metal and the support also have a different effect on the catalytic performance.

The scope of this paper is to investigate the effect of the configuration of the noble metal particle and the metal-support interaction on the catalytic performance of TWC in automobile emission control. $\mathrm{Ce}_{0.67} \mathrm{Zr}_{0.33} \mathrm{O}_{2}$ supported $\mathrm{Pd}$ catalysts that used three different $\mathrm{Pd}$ precursors, $\mathrm{H}_{2} \mathrm{PdCl}_{4}$ (chlorine-containing), $\mathrm{Pd}\left(\mathrm{NO}_{3}\right)_{2}$, and $\mathrm{Pd}\left(\mathrm{NH}_{3}\right)_{4}\left(\mathrm{NO}_{3}\right)_{2}$ (chlorine-free), were prepared by impregnation. Their physical and chemical properties were characterized by X-ray diffraction (XRD), CO chemisorption, X-ray photoelectron spectroscopy (XPS), high resolution transmission electron microscopy (HRTEM), $\mathrm{H}_{2}$-temperature program reduction ( $\mathrm{H}_{2}$-TPR) and in situ diffuse reflectance infrared transform spectroscopy (DRIFTS). These techniques helped acquire some insight into what improved the catalytic performance for $\mathrm{HC}, \mathrm{CO}$ and $\mathrm{NO}_{x}$ conversion in automobile exhaust.

\section{Experimental}

\subsection{Catalyst preparation}

$\mathrm{Ce}_{0.67} \mathrm{Zr}_{0.33} \mathrm{O}_{2}$ (CZ, $S_{\mathrm{BET}}=111 \mathrm{~m}^{2} / \mathrm{g}$ ) was prepared by the co-precipitation method [17]. Three $\mathrm{Pd} / \mathrm{Ce}_{0.67} \mathrm{Zr}_{0.33} \mathrm{O}_{2}$ catalysts with 1.0 wt\% loading were prepared with $\mathrm{CZ}$ using $\mathrm{H}_{2} \mathrm{PdCl}_{4}$, $\mathrm{Pd}\left(\mathrm{NO}_{3}\right)_{2}$ and $\mathrm{Pd}\left(\mathrm{NH}_{3}\right)_{4}\left(\mathrm{NO}_{3}\right)_{2}$ as metal precursor by incipient wetness impregnation at $30{ }^{\circ} \mathrm{C}$. The samples were dried at 110 ${ }^{\circ} \mathrm{C}$ for $4 \mathrm{~h}$ and then calcined at $500{ }^{\circ} \mathrm{C}$ in air for $2 \mathrm{~h}$. The sample prepared from the $\mathrm{H}_{2} \mathrm{PdCl}_{4}$ precursor was designated as $\mathrm{Pd} / \mathrm{CZ}(\mathrm{Cl})$, and that prepared from $\mathrm{Pd}\left(\mathrm{NO}_{3}\right)_{2}$ and $\mathrm{Pd}\left(\mathrm{NH}_{3}\right)_{4}\left(\mathrm{NO}_{3}\right)_{2}$ precursors were designated as $\mathrm{Pd} / \mathrm{CZ}(\mathrm{NO})$ and
$\mathrm{Pd} / \mathrm{CZ}(\mathrm{NH})$. TWCs are frequently exposed to very high temperature above $1000{ }^{\circ} \mathrm{C}$ in the application, which is the main reason resulting in decreased catalytic performance $[18,19]$. Therefore, the catalysts were also treated at $1000{ }^{\circ} \mathrm{C}$ for $4 \mathrm{~h}$ to get aged catalysts designated as $\mathrm{Pd} / \mathrm{CZ}(\mathrm{Cl})-\mathrm{a}, \mathrm{Pd} / \mathrm{CZ}(\mathrm{NO})$-a and $\mathrm{Pd} / \mathrm{CZ}(\mathrm{NH})-\mathrm{a}$, respectively.

\subsection{Catalytic performance test}

The three-way catalytic performance tests were carried out in a fixed bed continuous flow reactor at atmospheric pressure. $0.2 \mathrm{ml}$ catalyst $(0.3-0.45 \mathrm{~mm}, 0.276 \mathrm{~g})$ was used. The reaction mixture containing NO (0.121\%), $\mathrm{NO}_{2} \quad(0.034 \%), \quad \mathrm{C}_{3} \mathrm{H}_{6}$ (0.067\%), $\mathrm{C}_{3} \mathrm{H}_{8}(0.033 \%), \mathrm{CO}(0.748 \%), \mathrm{O}_{2}(0.745 \%)$ and balance $\mathrm{Ar}$ was fed to the reactor at a GHSV of $43000 \mathrm{~h}^{-1}$. The total flow rate was $143 \mathrm{ml} / \mathrm{min}$. The effluent gas was analyzed by an online Fourier transform infrared spectrophotometer (BRUKER EQ55) equipped with a multiple reflection transmission cell (Infrared Analysis Inc.; path length $10.0 \mathrm{~m}$ ). All spectra were taken at a resolution of $2 \mathrm{~cm}^{-1}$ using 128 scans [20].

\subsection{Characterization techniques}

XRD measurement was performed on an ARL X'TRA X-ray diffractometer (Thermo Electron Co.), operating at $40 \mathrm{kV}$ and $40 \mathrm{~mA}$ with Ni-filtered $\mathrm{Cu} K_{\alpha}$ radiation. The dispersion of $\mathrm{Pd}$ was calculated on the basis of $\mathrm{CO}$ chemisorption at room temperature [21-23] using a CHEMBET-3000 apparatus (Quantachrome Co.). The catalyst was first reduced under $\mathrm{H}_{2}$. CO chemisorption experiments were also performed with a Nicolet 6700 FTIR fitted with a MCT detector following the same pretreatment. The spectrum was recorded after $\mathrm{CO}$ adsorption at $30{ }^{\circ} \mathrm{C}$. The dispersion $(D)$ and palladium particle size $(d)$ were calculated as $[9,21,22]$ :

$$
\begin{gathered}
D(\%)=100 \times\left[\left(V_{\mathrm{s}} \times f\right) /\left(C_{\mathrm{s}} \times W_{\mathrm{s}} \times 22414\right)\right] \times m \\
d(\mathrm{~nm})=6 \times 105 \times m /\left(\rho_{\mathrm{Pd}} \times D \times S_{\mathrm{Pd}}\right)
\end{gathered}
$$

where $V_{\mathrm{s}}$ is the CO volume adsorbed ( $\mathrm{ml}$ at STP), $f$ is the stoichiometric factor (=1), $C_{\mathrm{s}}$ is $\mathrm{Pd}$ metal content (wt\%), $W_{\mathrm{s}}$ is the sample weight (g), $m$ is the Pd atomic mass $(106.42 \mathrm{~g} / \mathrm{mol}), D$ is $\mathrm{Pd}$ metal dispersion (\%), $n$ is Avogadro's number $\left(6.02 \times 10^{23}\right)$, $S_{\mathrm{Pd}}$ is molar surface area of Pd assuming an equidistribution of the low index faces ( $S=47780 \mathrm{~m}^{2} / \mathrm{mol}$ for Pd metal) and $\rho$ Pd is palladium density $\left(12 \mathrm{~g} / \mathrm{cm}^{3}\right)$.

XPS analysis was performed on a Thermo ESCALAB 250 spectrometer with $\mathrm{Al} K_{\alpha}$ radiation $(1486.6 \mathrm{eV}$ ) operating at 150 $\mathrm{W}$ and with an energy pass of $20 \mathrm{eV}$. The surface charging effect was corrected for by fixing the $\mathrm{C} 1 \mathrm{~s}$ peak at a binding energy of $284.8 \mathrm{eV}$. HRTEM analysis was carried out on a TECNAI G220 apparatus operated at $200 \mathrm{kV}$. XEDS analysis was used to record elemental maps to find the chemical composition. The sample for the HRTEM study was first dispersed in ethanol and deposited onto a perforated carbon film supported on a copper grid.

The oxygen storage capacity complete (OSCC) measurement was carried out using a CHEMBET-3000 apparatus (Quantachrome Co.). The sample (100 mg) was first reduced under $\mathrm{H}_{2}(10 \mathrm{ml} / \mathrm{min})$ at $550{ }^{\circ} \mathrm{C}$ for $60 \mathrm{~min}$, and then cooled 
down to $400{ }^{\circ} \mathrm{C}$ and flushed with $\mathrm{He}(30 \mathrm{ml} / \mathrm{min}$ ) for $30 \mathrm{~min}$. $0.15 \mathrm{ml}$ of $\mathrm{O}_{2}$ was pulsed into the sample bed every 5 min until no consumption of oxygen could be detected.

UV-Raman spectra were recorded on a UV-HR Raman spectrograph with a He-Gd laser of $325 \mathrm{~nm}$ excitation wavelength. It consisted of two data accumulation of $30 \mathrm{~s}$ with a resolution of $4 \mathrm{~cm}^{-1}$. A frequency range of $100-1000 \mathrm{~cm}^{-1}$ was observed. $\mathrm{H}_{2}$-TPR experiments were carried out on a GC-1690 chromatography. Each sample (50 mg) was pretreated under $\mathrm{N}_{2}(30$ $\mathrm{ml} / \mathrm{min}$ ) at $200{ }^{\circ} \mathrm{C}$ for $30 \mathrm{~min}$ and then cooled down to $-50{ }^{\circ} \mathrm{C}$ in liquid nitrogen. A flow of $5 \% \mathrm{H}_{2} / \mathrm{Ar}(40 \mathrm{ml} / \mathrm{min}$ ) was then switched into the system, and the temperature was raised to $900{ }^{\circ} \mathrm{C}$ at a rate of $10{ }^{\circ} \mathrm{C} / \mathrm{min}$. The consumption of $\mathrm{H}_{2}$ was measured by a thermal conductivity detector (TCD). The water formed during the program was absorbed with $5 \mathrm{~A}$ molecular sieve. Diffuse reflectance infrared Fourier transform spectroscopy (DRIFTS) studies were conducted on a Nicolet 6700 FTIR fitted with a MCT detector. The DRIFTS cell was fitted with $\mathrm{CaF}_{2}$ windows and a heating cartridge that allowed samples to be heated to $500{ }^{\circ} \mathrm{C}$. Spectra were collected at the resolution of 4 $\mathrm{cm}^{-1}$ using 32 scans. Prior to the infrared measurement, the sample was pretreated with $\mathrm{Ar}$ at $450{ }^{\circ} \mathrm{C}$ for $0.5 \mathrm{~h}$ and then cooled down to $30{ }^{\circ} \mathrm{C}$ in order to remove contaminants. The composition of the feed stream was the same as the catalytic performance test.

\section{Results and discussion}

\subsection{Catalytic performance}

Fig. 1 shows the conversion of $\mathrm{HC}, \mathrm{CO}, \mathrm{NO}$ and $\mathrm{NO}_{2}$ as a function of reaction temperature under stoichiometric $\mathrm{CO}+\mathrm{NO}_{x}+$ $\mathrm{HC}+\mathrm{O}_{2}$ flow over the fresh and aged catalysts. As shown in Fig. 1 , among the fresh catalysts, the Pd/CZ(NO) catalyst exhibited the best catalytic performance for $\mathrm{HC}$ and $\mathrm{CO}$ elimination. The $\mathrm{Pd} / \mathrm{CZ}(\mathrm{NH})$ catalyst exhibited good performance for $\mathrm{NO}$ and $\mathrm{NO}_{2}$ elimination. The $\mathrm{Pd} / \mathrm{CZ}(\mathrm{Cl})$ catalyst exhibited the worst catalytic performance. However, after the aging treatment, the $\mathrm{Pd} / \mathrm{CZ}(\mathrm{Cl})-\mathrm{a}$ catalyst exhibited the best catalytic performance for $\mathrm{HC}$ and $\mathrm{NO}_{2}$ conversion. The catalytic performance of both the $\mathrm{Pd} / \mathrm{CZ}(\mathrm{NO})-\mathrm{a}$ and $\mathrm{Pd} / \mathrm{CZ}(\mathrm{NH})$-a catalysts decreased except for $\mathrm{CO}$ elimination. It is known that chlorine has a strong interaction with ceria and it is hard to remove it completely when $\mathrm{H}_{2} \mathrm{PdCl}_{4}$ is the metal precursor. The chlorine residual in the fresh catalyst is harmful to the catalytic performance, probably due to the formation of $\mathrm{CeOCl}$, which can only be decomposed by an aging treatment $[24,25]$. This indicated that the catalytic performance of the Pd-supported catalysts could be affected by
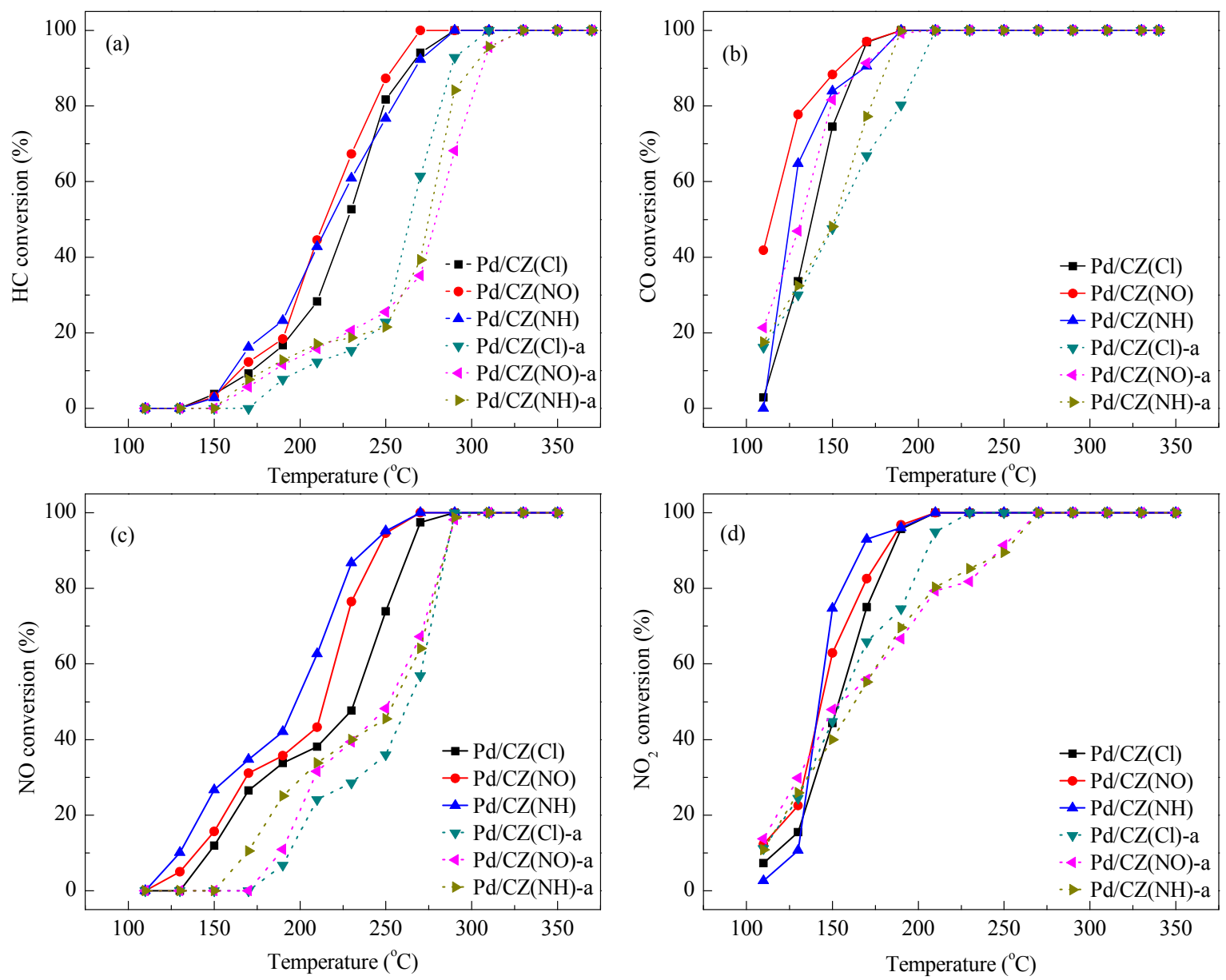

Fig. 1. Conversion of $\mathrm{HC}(\mathrm{a}), \mathrm{CO}(\mathrm{b}), \mathrm{NO}(\mathrm{c})$ and $\mathrm{NO}_{2}$ (d) as a function of reaction temperature under a stoichiometric $\mathrm{CO}+\mathrm{NO}_{x}+\mathrm{HC}+\mathrm{O}_{2}$ flow over fresh and aged catalysts. 
the nature of the Pd precursor.

\subsection{Pd dispersion and chemical state}

Pd dispersion of the fresh and aged catalysts was determined by $\mathrm{CO}$ chemisorption at room temperature. The results are listed in Table 1 . The amount of CO bonded to the CZ support is very small after the heat treatment compared with the large amount of $\mathrm{CO}$ chemisorbed on the Pd/CZ catalysts, and it can be ignored. From Table 1, we can see that the fresh catalysts exhibited high $\mathrm{Pd}$ dispersion, indicating that the $\mathrm{PdO}_{x}$ species were well dispersed on the $\mathrm{CZ}$ support. The Pd dispersion order was $\mathrm{Pd} / \mathrm{CZ}(\mathrm{NH})>\mathrm{Pd} / \mathrm{CZ}(\mathrm{NO})>\mathrm{Pd} / \mathrm{CZ}(\mathrm{Cl})$. During the preparation, the $\mathrm{pH}$ of the $\mathrm{H}_{2} \mathrm{PdCl}_{4}$ and $\mathrm{Pd}\left(\mathrm{NO}_{3}\right)_{2}$ precursor solution was 2 , and that of the $\mathrm{Pd}\left(\mathrm{NH}_{3}\right)_{4}\left(\mathrm{NO}_{3}\right)_{2}$ precursor solution was 6. As studied by Kuno [26], the isoelectric point is in a range from 3.8 to 5.0 when the molar ratio $\mathrm{Ce} / \mathrm{Zr}$ ranged from $3 / 7$ to $7 / 3$. The $\mathrm{CZ}$ support has a positive charge in the $\mathrm{H}_{2} \mathrm{PdCl}_{4}$ and $\mathrm{Pd}\left(\mathrm{NO}_{3}\right)_{2}$ precursor solution, and a slight negative charge in the $\mathrm{Pd}\left(\mathrm{NH}_{3}\right)_{4}\left(\mathrm{NO}_{3}\right)_{2}$ precursor solution. In the three precursor solutions, $\mathrm{Pd}$ species existed as $\mathrm{PdCl}_{4}{ }^{2-}, \mathrm{Pd}^{2+}$, and $\mathrm{Pd}\left(\mathrm{NH}_{3}\right)^{4+}$, respectively. The electrostatic interaction between $\mathrm{PdCl}_{4}{ }^{2-}$ and the $\mathrm{CZ}$ support is stronger. Besides this, the strong interaction between chlorine and ceria also inhibited the activation of active $\mathrm{PdO}_{x}$ species and redispersion of $\mathrm{PdO}_{x}$ species by calcination at $500{ }^{\circ} \mathrm{C}$. Therefore the fresh catalyst prepared with the $\mathrm{H}_{2} \mathrm{PdCl}_{4}$ precursor showed low dispersion. Compared to $\mathrm{Pd}^{2+}$, $\mathrm{Pd}\left(\mathrm{NH}_{3}\right)_{4}{ }^{2+}$ ions has a steric hindrance effect which helps to keep Pd isolated from each other, resulting in the $\mathrm{Pd} / \mathrm{CZ}(\mathrm{NH})$ catalyst showing a better $\mathrm{Pd}$ dispersion than $\mathrm{Pd} / \mathrm{CZ}(\mathrm{NO})$. The particle size order was $\mathrm{Pd} / \mathrm{CZ}(\mathrm{NH})<\mathrm{Pd} / \mathrm{CZ}(\mathrm{NO})<\mathrm{Pd} / \mathrm{CZ}(\mathrm{Cl})$. For the aged catalysts, the Pd dispersion order was $\mathrm{Pd} / \mathrm{CZ}(\mathrm{Cl})-\mathrm{a}$ $>\mathrm{Pd} / \mathrm{CZ}(\mathrm{NO})-\mathrm{a} \approx \mathrm{Pd} / \mathrm{CZ}(\mathrm{NH})-\mathrm{a}$, and the mean particle size of $\mathrm{Pd}$
Table 1

CO chemisorption quantity, dispersion, particle size of Pd and CO adsorption quantity of the three $\mathrm{CO}-\mathrm{Pd}^{0}$ species over the fresh and aged catalysts.

\begin{tabular}{lcrrc}
\hline Catalyst & $\begin{array}{c}n_{\mathrm{Co}}{ }^{\mathrm{a}} \\
\left(\mu \mathrm{mol} / \mathrm{g}_{\mathrm{cat}}\right)\end{array}$ & $\begin{array}{c}D^{\mathrm{b}} \\
(\%)\end{array}$ & $\begin{array}{c}D^{\mathrm{c}} \\
(\mathrm{nm})\end{array}$ & $\begin{array}{c}n_{\mathrm{co}} \text { of atop, bridge, 3-fold } \\
\text { CO-Pd }^{0} \text { species }^{\mathrm{d}}\left(\mu \mathrm{mol} / \mathrm{g}_{\mathrm{cat}}\right)\end{array}$ \\
\hline $\mathrm{Pd} / \mathrm{CZ}(\mathrm{Cl})$ & 17.7 & 20.1 & 5.5 & \multicolumn{1}{c}{$4.8,3.3,9.6$} \\
$\mathrm{Pd} / \mathrm{CZ}(\mathrm{NO})$ & 23.0 & 24.5 & 4.5 & $13.1,3.6,6.3$ \\
$\mathrm{Pd} / \mathrm{CZ}(\mathrm{NH})$ & 37.4 & 39.8 & 2.8 & $12.0,8.1,17.3$ \\
$\mathrm{Pd} / \mathrm{CZ}(\mathrm{Cl})-\mathrm{a}$ & 7.6 & 8.6 & 12.9 & $3.7,1.2,2.7$ \\
$\mathrm{Pd} / \mathrm{CZ}(\mathrm{NO})-\mathrm{a}$ & 5.9 & 6.3 & 17.7 & $2.7,1.1,2.1$ \\
$\mathrm{Pd} / \mathrm{CZ}(\mathrm{NH})-\mathrm{a}$ & 5.4 & 5.7 & 19.5 & $3.1,0.7,1.6$ \\
\hline
\end{tabular}

${ }^{a}$ Amount of $\mathrm{CO}$ chemisorbed on Pd surface. ${ }^{\mathrm{b}} \mathrm{Pd}$ dispersion determined by CO chemisorption. ${ }^{\mathrm{c}}$ Mean particle size calculated from Pd dispersion. ${ }^{\mathrm{d}}$ Calculated from the ratio of top/bridge/3-fold CO-Pd ${ }^{0}$ species and total CO chemisorption quantity.

in $\mathrm{Pd} / \mathrm{CZ}(\mathrm{Cl})$-a catalyst was smaller than in the other two catalysts. According to the catalytic performance test, $\mathrm{Pd} / \mathrm{CZ}(\mathrm{NH})$ and $\mathrm{Pd} / \mathrm{CZ}(\mathrm{NO})$ showed better catalytic performance for $\mathrm{CO}$, $\mathrm{HC}$, and $\mathrm{NO}_{x}$ conversion than the $\mathrm{Pd} / \mathrm{CZ}(\mathrm{Cl})$ catalyst, but the $\mathrm{Pd} / \mathrm{CZ}(\mathrm{Cl})$ catalyst lost the least catalytic activity after the aging treatment. This indicated that highly dispersed $\mathrm{PdO}_{x}$ species play a role in $\mathrm{CO}, \mathrm{HC}$ and $\mathrm{NO}_{x}$ conversion. However, the $\mathrm{CO}$ conversion is significantly promoted by oxygen-storage materials and influenced by the OSC of the catalyst [27]. It is not only the configuration of the $\mathrm{PdO}_{x}$ particles on the surface of support but also the noble metal-support interaction that play an important role in NO conversion [27]. In order to obtain more information about the configuration of the $\mathrm{PdO}_{x}$ particles, the XRD, HRTEM, IR, and XPS results of the catalysts were analyzed.

HRTEM images of the fresh and aged catalysts are shown in Fig. 2. With all the fresh catalysts, only the $\mathrm{CZ}$ oxide was observed with an interplanar spacing of $0.31 \mathrm{~nm}$ corresponding to

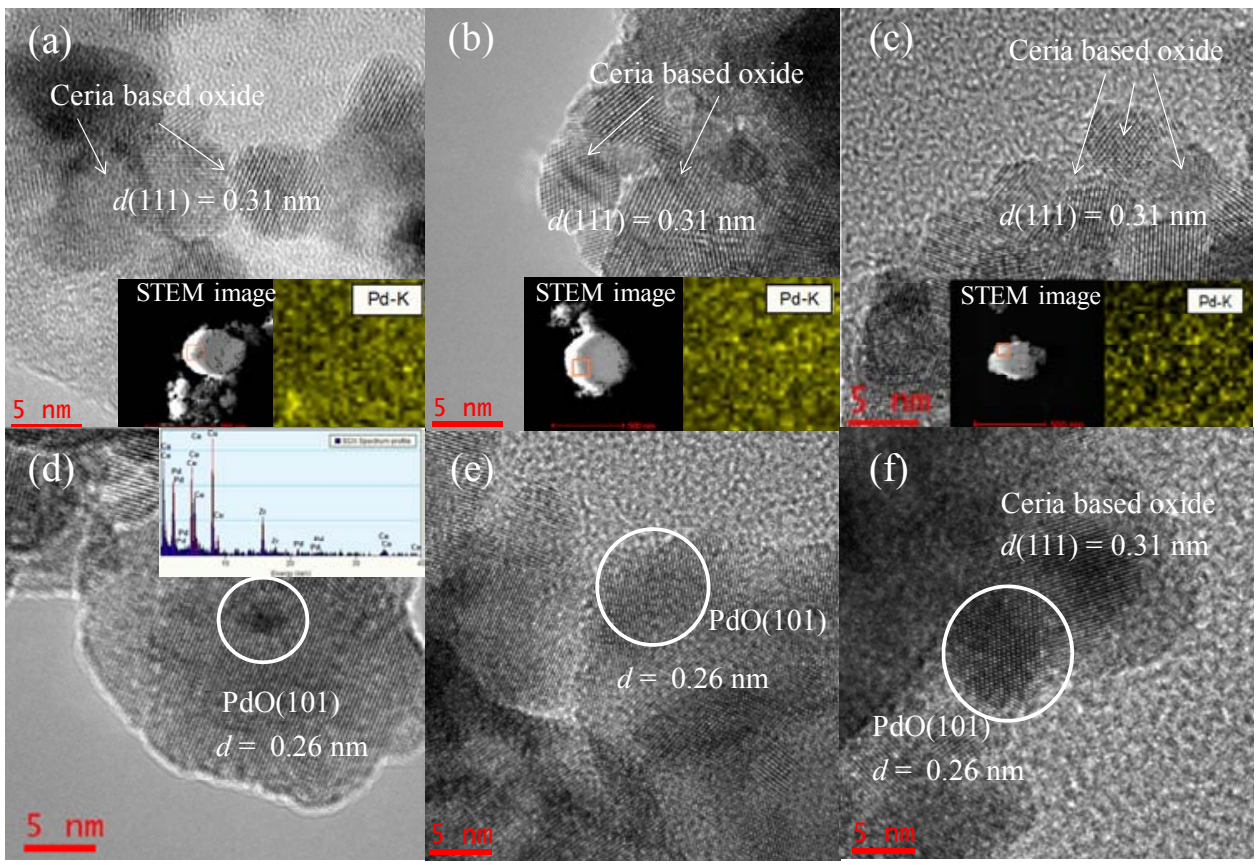

Fig. 2. HRTEM images of Pd/CZ(Cl) (a), Pd/CZ(NO) (b), Pd/CZ(NH) (c), Pd/CZ(Cl)-a (d), Pd/CZ(NO)-a (e), and Pd/CZ(NH)-a (f) catalyst. The insets in (a), (b) and (c) are the corresponding STEM and EDS elemental mapping of Pd. 
$\mathrm{CeO}_{2}$ (111). The particle size was $5 \mathrm{~nm}$. No $\mathrm{PdO}_{x}$ particle was found because Pd clusters are hard to observe owing to a lack of contrast with the support. In order to look at the distribution of $\mathrm{PdO}_{x}$ species on the fresh catalysts, we also measured the elemental mapping on the $\mathrm{Pd} / \mathrm{CZ}(\mathrm{Cl})$ and $\mathrm{Pd} / \mathrm{CZ}(\mathrm{NO})$ and $\mathrm{Pd} / \mathrm{CZ}(\mathrm{NH})$ catalysts. The bright squares in the insets of Fig. $2(\mathrm{a}-\mathrm{c})$ were attributed to high concentration $\mathrm{PdO}_{x}$ species, unlike the slight aggregation in the $\mathrm{Pd} / \mathrm{CZ}(\mathrm{Cl})$ catalyst (shown in circle, Fig. 2(a)). The bright squares in the Pd/CZ(NO) and $\mathrm{Pd} / \mathrm{CZ}(\mathrm{NH})$ catalysts were more isolated, meaning that the $\mathrm{PdO}_{x}$ species were uniformly distributed on the surface of support, in agreement with the result of the Pd dispersion measurement. Moreover, no $\mathrm{CeOCl}$ lattice fringes were determined in the $\mathrm{Pd} / \mathrm{CZ}(\mathrm{Cl})$ catalyst, which was probably due to the low chlorine content from the $\mathrm{H}_{2} \mathrm{PdCl}_{4}$ precursor. After the aging treatment, based on the EDX spot spectrum taken from the region of the circled particle in Fig. 2(d), the lattice fringes with the interplanar spacing of $0.26 \mathrm{~nm}$ was determined to be associated with the (101) facet of PdO. PdO particles on the aged catalysts were observed as a result of the high aging temperature leading to a sintering of PdO. However, it was obvious that the $\mathrm{Pd} / \mathrm{CZ}(\mathrm{Cl})$-a catalyst showed a smaller diameter of PdO particles compared with the other catalysts, in agreement with the calculated Pd particle size order calculated from the Pd dispersion measurement. This was one of the reasons why the $\mathrm{Pd} / \mathrm{CZ}(\mathrm{Cl})$ catalyst still has a good catalytic performance after the aging treatment.

In general, when calculating the dispersion, the stoichiometric factor $f(\mathrm{Pd} / \mathrm{CO})$ is assumed as 1 [21,22], while the adsorption of $\mathrm{CO}$ on the Pd metal sites has top, bridge and 3-fold forms [28-31], which depends on the configuration of the active components, in terms of the particle size and also particle shape. In order to clarify these aspects, the catalysts were examined by in situ DRIFTS. The DRIFTS spectra of CO chemisorption at $30{ }^{\circ} \mathrm{C}$ over the in situ reduced catalysts are shown in Fig. 3. The band at $2115-2025 \mathrm{~cm}^{-1}$ corresponded to on-top carbonyl species chemisorbed on metallic Pd particles. Another band that appeared at $1980-1900 \mathrm{~cm}^{-1}$ can be ascribed to carbonyl species chemisorbed on bridge sites of metallic Pd particles. A third carbonyl species that appeared as a low frequency shoulder extending to $1900-1800 \mathrm{~cm}^{-1}$. This shoulder can be ascribed to carbonyl species chemisorbed on threefold sites of metallic Pd particles [32]. The order of the total area of the carbonyl adsorption peaks in the fresh and aged catalysts was $\mathrm{Pd} / \mathrm{CZ}(\mathrm{NH})>\mathrm{Pd} / \mathrm{CZ}(\mathrm{NO})>\mathrm{Pd} / \mathrm{CZ}(\mathrm{Cl}), \mathrm{Pd} / \mathrm{CZ}(\mathrm{Cl})-\mathrm{a}>$ $\mathrm{Pd} / \mathrm{CZ}(\mathrm{NO})-\mathrm{a} \approx \mathrm{Pd} / \mathrm{CZ}(\mathrm{NH})-\mathrm{a}$, which agreed with metallic dispersion measurement results. From Table 1 and Fig. 3(a), we can find that the $\mathrm{Pd} / \mathrm{CZ}(\mathrm{NO})$ catalyst showed an obvious increase in on-top $\mathrm{CO}-\mathrm{Pd}^{0}$ species compared with $\mathrm{Pd} / \mathrm{CZ}(\mathrm{Cl})$, suggesting that more small $\mathrm{Pd}_{n}$ clusters existed on the $\mathrm{Pd} / \mathrm{CZ}(\mathrm{NO})$ catalyst surface. High dispersion and small clusters give more active sites and promote oxygen transfer, which is beneficial to $\mathrm{CO}$ and $\mathrm{HC}$ oxidation [33,34]. Therefore, the $\mathrm{Pd} / \mathrm{CZ}(\mathrm{NO})$ catalyst exhibited the best oxidation of $\mathrm{CO}$ and $\mathrm{HC}$ activity at low temperatures. The $\mathrm{Pd} / \mathrm{CZ}(\mathrm{NH})$ catalyst showed an obvious increase in bridge and 3 -fold $\mathrm{CO}-\mathrm{Pd}^{0}$ species, indicating that a larger amount of relatively big $\mathrm{Pd}_{n}$ clusters existed on the $\mathrm{Pd} / \mathrm{CZ}(\mathrm{NH})$ catalyst surface. NO reduction is a structure sensitive reaction [27]. Therefore, abundant bigger $\mathrm{Pd}_{n}$ clusters facilitate the increase in NO reduction activity. As mentioned above, the important difference in the position of the $\mathrm{CO}$ absorption peak demonstrated clearly that the nature of the $\mathrm{Pd}$ precursor has a significant effect on the physicochemical properties of the $\mathrm{PdO}_{x}$ species on the surface of the support. In addition, compared with that of the fresh catalysts, from Table 1 and Fig. 3(b), it can be seen that both small $\mathrm{Pd}_{n}$ clusters and also the big $\mathrm{Pd}_{n}$ clusters on the aged catalyst surface were decreased, which indicated that the high temperature calculation led to the sintering of $\mathrm{PdO}_{x}$ species. However, the $\mathrm{Pd} / \mathrm{CZ}(\mathrm{Cl})-\mathrm{a}$ catalyst still had more small $\mathrm{Pd}_{n}$ clusters, which helped the $\mathrm{Pd} / \mathrm{CZ}(\mathrm{Cl})-\mathrm{a}$ catalyst keep a good catalytic performance for $\mathrm{HC}$ conversion.

The change of the electronic state of the Pd species was investigated by XPS. The Pd $3 d$ XPS spectra of the catalysts before and after the aging treatment are shown in Fig. 4. The BE values of $\mathrm{Pd} 3 d_{5 / 2}$ in these catalysts were $336.7-337.7 \mathrm{eV}$ corresponding to the PdO state $[31,35]$. Compared with the $\mathrm{Pd} / \mathrm{CZ}(\mathrm{Cl})$ catalyst, the peaks of the $\mathrm{Pd} / \mathrm{CZ}(\mathrm{NO})$ and $\mathrm{Pd} / \mathrm{CZ}(\mathrm{NH})$ catalysts were shifted to higher BEs. This was ascribed to the smaller particle size of PdO, in accord with the Kobayashi et al. [36]
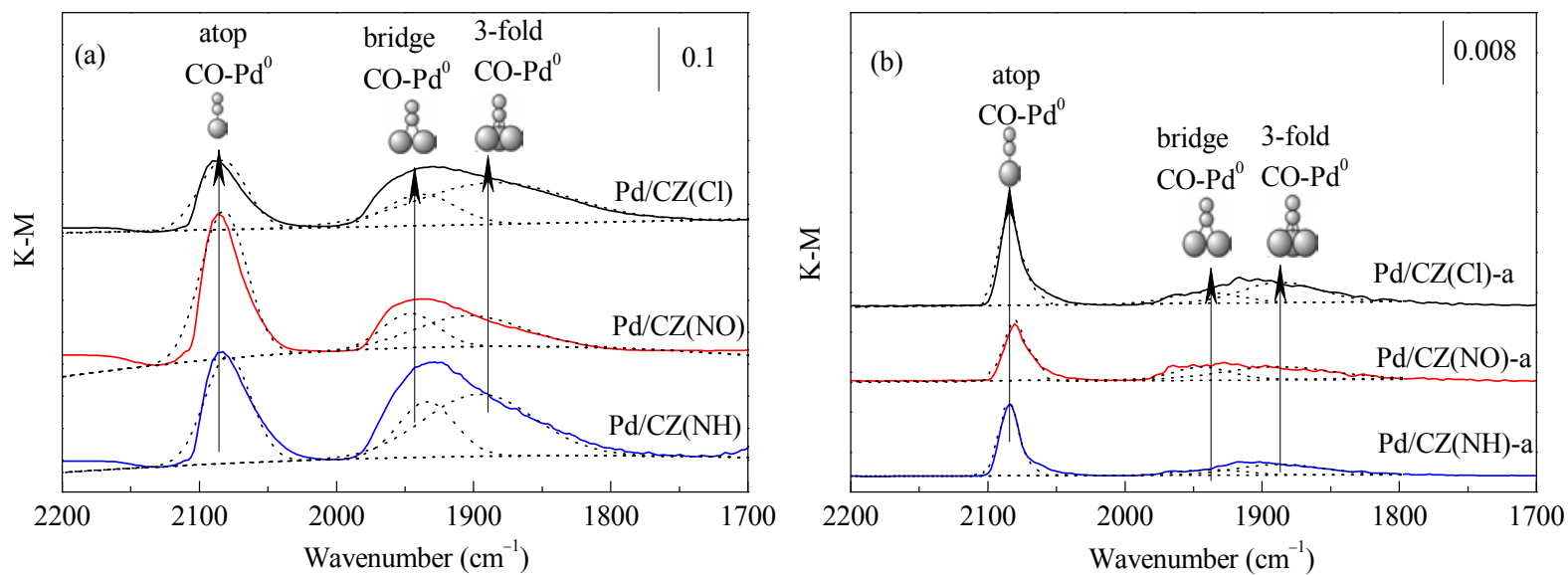

Fig. 3. IR spectra of $\mathrm{CO}$ adsorbed on the fresh (a) and aged (b) $\mathrm{Pd} / \mathrm{CZ}(\mathrm{Cl}), \mathrm{Pd} / \mathrm{CZ}(\mathrm{NO})$ and $\mathrm{Pd} / \mathrm{CZ}(\mathrm{NH})$ catalysts at $30^{\circ} \mathrm{C}$ after the same pretreatment as the Pd dispersion measurement. 

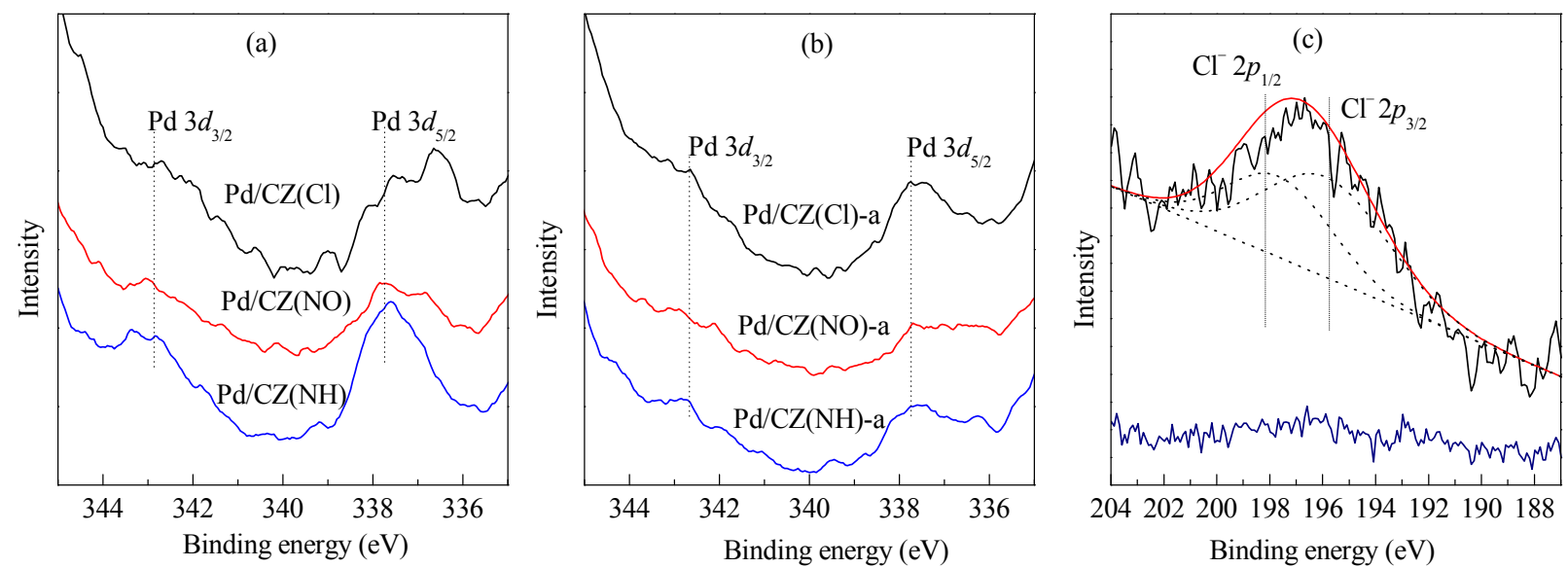

Fig. 4. Pd $3 d$ XPS spectra for fresh (a) and aged (b) catalysts and $\mathrm{Cl} 2 p$ spectra for fresh and aged Pd/CZ catalysts (c).

study that the interaction between small $\mathrm{PdO}_{x}$ particles and the support is stronger, improving the electron transfer from $\mathrm{PdO}_{x}$ particles to the $\mathrm{CZ}$ support and leading Pd to be in a more oxidized state. After the aging treatment, the $\mathrm{BE}$ of $\mathrm{Pd} 3 d_{5 / 2}$ for $\mathrm{Pd} / \mathrm{CZ}(\mathrm{NO})$-a and Pd/CZ(NH)-a shifted to a lower value due to the sintering of $\mathrm{PdO}$, while that for $\mathrm{Pd} / \mathrm{CZ}(\mathrm{Cl})$-a did not change much, indicating that the $\mathrm{PdO}_{x}$ species in $\mathrm{Pd} / \mathrm{CZ}(\mathrm{Cl})$-a still kept a relatively high dispersion, in agreement with the Pd dispersion measurement. Another reason may be that the $\mathrm{CeOCl}$ phase decomposed under the high temperature oxidizing conditions [25,37,38], resulting in more oxygen vacancies being formed on the $\mathrm{CZ}$ support and promoting the electron transfer from Pd to CZ. The Cl $2 p$ XPS spectra of the fresh and aged $\mathrm{Pd} / \mathrm{CZ}(\mathrm{Cl})$ catalysts (Fig. 4 (c)) also showed the exist of $\mathrm{Cl}$ species on the $\mathrm{Pd} / \mathrm{CZ}(\mathrm{Cl})$ catalyst, while no $\mathrm{Cl}$ peak was detected for the $\mathrm{Pd} / \mathrm{CZ}(\mathrm{Cl})$-a catalyst.

According to the analysis above, there were more small $\mathrm{Pd}_{n}$ clusters on the $\mathrm{Pd} / \mathrm{CZ}(\mathrm{NO})$ catalyst prepared with $\mathrm{Pd}\left(\mathrm{NO}_{3}\right)_{2}$ as the precursor, leading to a stronger interaction between the small $\mathrm{PdO}_{x}$ particles and support, which kept Pd in a more oxidized state and promoted the oxidation conversion of $\mathrm{HC}$ and CO. For the Pd/CZ(NH) catalyst, the higher Pd dispersion and abundant bigger $\mathrm{Pd}_{n}$ clusters resulted in good performance for $\mathrm{NO}$ and $\mathrm{NO}_{2}$ elimination. The $\mathrm{Pd} / \mathrm{CZ}(\mathrm{Cl})$ catalyst exhibited a low catalytic activity due to the relatively low Pd dispersion, weak Pd-support interaction and stable $\mathrm{CeOCl}$ species inhibiting oxygen vacancy creation. However, it exhibited good thermal stability as a result of the residual chlorine species being removed after the aging treatment.

\section{3. $\quad$ OSC and oxygen vacancies studies}

OSC of the catalyst is regarded as one of the most important parameters in the application. Table 2 gives the OSC of the catalysts at $400{ }^{\circ} \mathrm{C}$ and shows that the OSC of the fresh samples was in the order of $\mathrm{Pd} / \mathrm{CZ}(\mathrm{NO})>\mathrm{Pd} / \mathrm{CZ}(\mathrm{NH})>\mathrm{Pd} / \mathrm{CZ}(\mathrm{Cl})$,

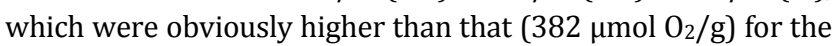
CZ support, indicating that a PdO-support interaction promoted the back-spillover of oxygen between support and active $\mathrm{PdO}_{x}$ species $[12,31]$. The obviously increased OSC in the Pd/CZ(NO) catalyst means a stronger PdO-support interaction. Thus, the $\mathrm{Pd} / \mathrm{CZ}(\mathrm{NO})$ catalyst showed the highest catalytic activity for CO oxidation. After the aging treatment, a loss of OSC occurred due to the sintering of the support and highly dispersed $\mathrm{PdO}_{x}$ species, which resulted in the $\mathrm{PdO}$-support interaction weakening. For the $\mathrm{Pd} / \mathrm{CZ}(\mathrm{Cl})$-a catalyst, the surface $\mathrm{Cl}$ was removed and new oxygen vacancies created after the aging treatment. Thus, the aged catalyst showed a similar OSC performance.

Generally speaking, the oxygen vacancy concentration in the CZ support is in accordance with the OSC performance. Therefore, Raman characterization of the fresh and aged catalysts was carried out. The result is shown in Fig. 5 . The Raman band at $450 \mathrm{~cm}^{-1}$ was attributed to the $F_{2 g}$ vibration mode of the fluorite structure of $\mathrm{CeO}_{2}$. The band at $630 \mathrm{~cm}^{-1}$ was ascribed to the non-degenerate LO mode of ceria as a result of the relaxation of symmetry rules, which is related to oxygen vacancies or lattice defects in the ceria lattice [39-41]. Another weak band observed at $320 \mathrm{~cm}^{-1}$ can be ascribed to the displacement of oxygen atoms from their ideal fluorite lattice positions [42]. It is well known that the concentration of oxygen vacancies can be observed by the ratio of the peak areas of the bands at 450 (A450) and $630 \mathrm{~cm}^{-1}\left(A_{630}\right)$. For the fresh catalysts, Pd/CZ(NO) exhibited the highest $A_{630} / A_{450}$, and the order of $A_{630} / A_{450}$ for the three catalysts was $\mathrm{Pd} / \mathrm{CZ}(\mathrm{NO})>\mathrm{Pd} / \mathrm{CZ}(\mathrm{NH})>\mathrm{Pd} / \mathrm{CZ}(\mathrm{Cl})$, which is in good agreement with their OSC values. The result indicated that the amount of oxygen vacancies in the catalysts was also strongly affected by the PdO-support interaction. The strong interaction between $\mathrm{Pd}$ and the support would promote the reduction of ceria at the $\mathrm{Pd}-\mathrm{CZ}$ interface, which increases the oxygen vacancies concentration and OSC performance. Af-

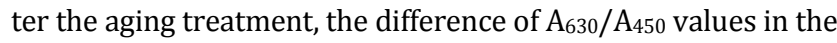
catalysts became negligible. Thus, the aged catalysts have similar OSC performance. However, compared with fresh

\section{Table 2}

Oxygen storage capacity and $A_{630} / A_{450}$ of fresh and aged catalysts.

\begin{tabular}{lccccc}
\hline \multirow{2}{*}{ Catalyst } & \multicolumn{2}{c}{ OSC $\left(\mu \mathrm{mol} \mathrm{O}_{2} / \mathrm{g}\right)$} & & \multicolumn{2}{c}{$A_{630} / A_{450}$} \\
\cline { 2 - 3 } \cline { 5 - 6 } & Fresh & Aged & & Fresh & Aged \\
\hline Pd/CZ(Cl) & 556 & 458 & & 1.03 & 1.15 \\
Pd/CZ(NO) & 696 & 445 & & 1.27 & 1.08 \\
Pd/CZ(NH) & 642 & 462 & & 1.24 & 1.10 \\
\hline
\end{tabular}




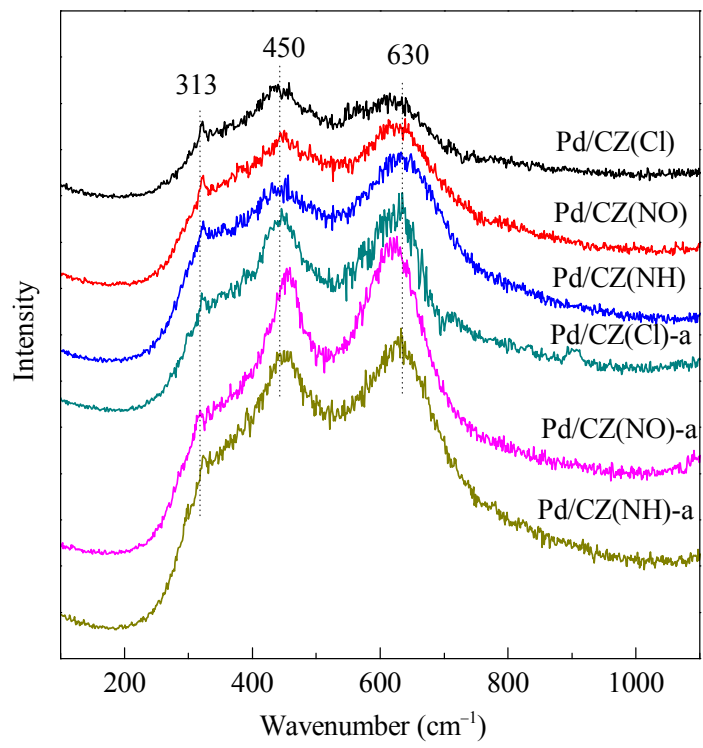

Fig. 5. UV-Raman spectra of the fresh and aged catalysts.

$\mathrm{Pd} / \mathrm{CZ}(\mathrm{Cl})$, the $A_{630} / A_{450}$ for the $\mathrm{Pd} / \mathrm{CZ}(\mathrm{Cl})-\mathrm{a}$ catalyst was slightly increased because the residual chlorine species that have a strong interaction with ceria was removed.

\subsection{Redox properties studies}

$\mathrm{H}_{2}$-TPR is a convenient way to characterize the redox properties of the samples. The different dispersion state of the $\mathrm{PdO}_{x}$ species and interaction with the support has a large effect on the redox properties of the catalysts. The $\mathrm{H}_{2}$-TPR results of the fresh and aged catalysts are shown in Fig. 6. We can see that the $\mathrm{H}_{2}$-TPR profiles of the fresh catalysts showed two hydrogen consumption peaks ( $\alpha$ and $\beta$ ) below $150{ }^{\circ} \mathrm{C}$, which can be assigned to the reduction of $\mathrm{PdO}_{x}$ species highly dispersed on the surface of the support and stable PdO species having a strong interaction with support, respectively $[6,43]$. However, according to the calculation (using a standard $\mathrm{CuO}$ sample with a similar TPR procedure), the total $\mathrm{H}_{2}$ consumption of peaks $\alpha$ and $\beta$ in three catalysts were 541,627 , and $534 \mu \mathrm{mol} / \mathrm{g}_{\text {cat, }}$ respectively, much higher than the nominal value $\left(94 \mu \mathrm{mol} / \mathrm{g}_{\mathrm{cat}}\right)$.
These were too large to be reasonably assigned to the reduction of $\mathrm{PdO}_{x}$, suggesting that the presence of Pd promoted the adsorption and spillover of hydrogen from the noble metal particles to the support due to the strong interaction between $\mathrm{Pd}$ and $\mathrm{CZ}$, leading to interfacial $\mathrm{Ce}^{4+}$ reduction at low temperature $[44,45]$. In addition, a negative peak at $70{ }^{\circ} \mathrm{C}$ was observed for the catalysts, especially for the $\mathrm{Pd} / \mathrm{CZ}(\mathrm{Cl})$ catalyst, which is generally attributed to the decomposition of palladium hydride $[17,20]$. The existence of large Pd particles favors the formation and decomposition of the $\mathrm{PdH}_{x}$ phase $[16,46]$, and the larger Pd particles have the more obvious decomposition peak of palladium hydride. This indicated that $\mathrm{PdO}_{x}$ species with a large size existed on the $\mathrm{Pd} / \mathrm{CZ}(\mathrm{Cl})$ catalyst. Several previous investigations have reported that the catalytic performance coincides with the redox properties of the active species $[47,48]$. However, in the three-way catalytic reaction system, the redox properties of the active Pd species are not the main reason for catalytic performance. According to the catalytic performance test, the $\mathrm{Pd} / \mathrm{CZ}(\mathrm{Cl})$ catalyst exhibited the lowest catalytic activity of $\mathrm{CO}, \mathrm{HC}$, and $\mathrm{NO}_{x}$ conversion compared with $\mathrm{Pd} / \mathrm{CZ}(\mathrm{NO})$ and $\mathrm{Pd} / \mathrm{CZ}(\mathrm{NH})$, which may have a relationship with the chloride-based preparation that is extensively used in industrial synthesis. The residual chloride, low Pd dispersion, and weak Pd-support interaction led to poor catalytic performance for the $\mathrm{Pd} / \mathrm{CZ}(\mathrm{Cl})$ catalyst.

Significant changes in the reduction characteristics occurred for the catalysts after the aging treatment in Fig. 6(b). The decomposition peaks of palladium hydride became more obvious and the intensity of the reduction peaks $(\alpha)$ at low temperature was weakened, implying that $\mathrm{PdO}_{x}$ species were sintered after aging. However, it is worth noting that after the aging treatment, the intensity of the reduction peaks $(\beta)$ was obviously increased and the peaks shifted to higher temperature, which suggested that the PdO species on the surface of the CZ support can migrate and more stable PdO species having a strong interaction with the support were formed at the high temperature of $1000{ }^{\circ} \mathrm{C}$. From Fig. 6(b), it can also be found that the temperature of the reduction $\beta$ peak over $\mathrm{Pd} / \mathrm{CZ}(\mathrm{Cl})-\mathrm{a}$ was lower than that of the other two catalysts, and this may be one of the reasons why the $\mathrm{Pd} / \mathrm{CZ}(\mathrm{Cl})-$ a catalyst has a better catalytic performance.
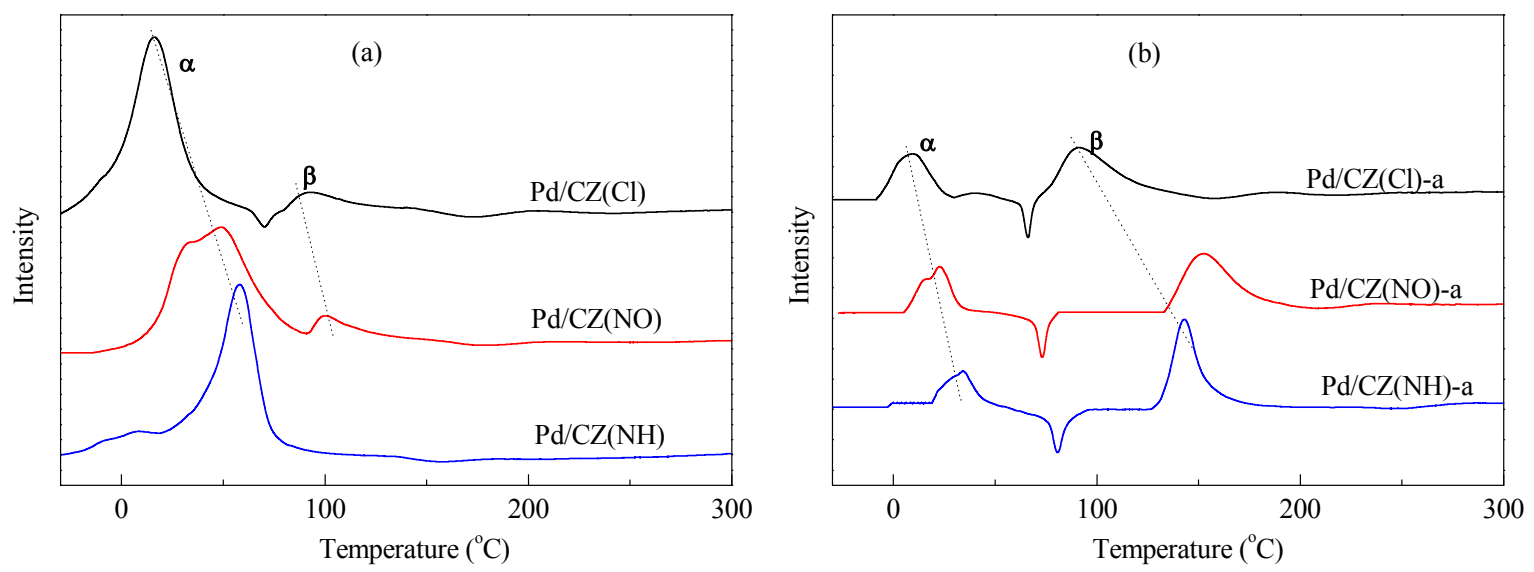

Fig. 6. $\mathrm{H}_{2}$-TPR profiles of the fresh (a) and aged (b) catalysts. 


\subsection{In situ DRIFTS studies}

In order to find a potential relationship between the particular $\mathrm{PdO}_{x}$ species and catalytic behavior during the light off process, in situ DRIFTS studies under a stoichiometric HC-CO-NO $\mathrm{N}_{x}-\mathrm{O}_{2}$ flow were performed. DRIFTS spectra obtained every $20{ }^{\circ} \mathrm{C}$ under reaction conditions over the $\mathrm{Pd} / \mathrm{CZ}(\mathrm{Cl})$, $\mathrm{Pd} / \mathrm{CZ}(\mathrm{NO})$ and $\mathrm{Pd} / \mathrm{CZ}(\mathrm{NH})$ catalysts are shown in Fig. 7. The bands in the region of $1800-2300 \mathrm{~cm}^{-1}$ can be attributed to $\mathrm{NCO}$ and carbonyls species adsorbed on different $\mathrm{PdO}_{\mathrm{x}}$ sites [29-31,49]. Overlap of the $\mathrm{CO}(\mathrm{g})$ features, showing two symmetrical bands at 2120 and $2170 \mathrm{~cm}^{-1}$, has been subtracted from all spectra. From Fig. 7(a), it can be seen that for the $\mathrm{Pd} / \mathrm{CZ}(\mathrm{Cl})$ catalyst, the presence of carbonyl adsorbed on $\mathrm{Pd}^{2+}$ $\left(2161 \mathrm{~cm}^{-1}\right)$ was observed from 30 to $110{ }^{\circ} \mathrm{C}$, no band corresponding to carbonyl chemisorbed on $\mathrm{Pd}^{+}$or $\mathrm{Pd}^{0}$ was observed below $130{ }^{\circ} \mathrm{C}$. This indicated that oxidized Pd species dominated the surface of the $\mathrm{Pd} / \mathrm{CZ}(\mathrm{Cl})$ catalyst. Weak features at 2071 and $1960 \mathrm{~cm}^{-1}$ that showed on-top and bridge carbonyls adsorbed on $\mathrm{Pd}^{0}$ sites were observed at 150 and $170{ }^{\circ} \mathrm{C}$. This means the initially present $\mathrm{PdO}$ species were partly converted to $\mathrm{Pd}^{0}$ particles under reaction conditions. When the temperature was increased up to $190^{\circ} \mathrm{C}$, these bands disappeared due to decreasing $\mathrm{CO}$ coverage caused by $\mathrm{CO}$ desorption and increasing CO conversion, which agreed with the light-off temperature of CO conversion in the catalytic performance test. A new band at $2179 \mathrm{~cm}^{-1}$ was observed above $190^{\circ} \mathrm{C}$. This was attributed to NCO species formed by $\mathrm{N}-\mathrm{O}$ dissociation and subsequent bonding with $\mathrm{CO}(\mathrm{g})$ on $\mathrm{Pd}^{0}$ sites. The formation of
NCO species is an important path for NO reduction and usually the strong intensity of the band is regarded as a useful fingerprint for monitoring NO dissociation [27,30]. Moreover, it is interesting that a band at $2001 \mathrm{~cm}^{-1}$ was also observed when the reaction temperature was increased up to $230{ }^{\circ} \mathrm{C}$. According to the results of $\mathrm{H}_{2}$-TPR and CO-DRIFTS, there were two kinds of $\mathrm{PdO}_{x}$ species dispersed on the catalysts, thus, the band may be also related to NCO species produced on another kind of $\mathrm{Pd}^{0}$ sites. For the $\mathrm{Pd} / \mathrm{CZ}(\mathrm{NO})$ and $\mathrm{Pd} / \mathrm{CZ}(\mathrm{NH})$ catalysts as shown in Fig. 7(b) and (c), there were similar bands to the $\mathrm{Pd} / \mathrm{CZ}(\mathrm{Cl})$ catalyst. But compared with the $\mathrm{Pd} / \mathrm{CZ}(\mathrm{Cl})$ catalyst, initial oxidized PdO species on the Pd/CZ(NO) catalyst were more easily converted to $\mathrm{Pd}^{0}$ particles under reaction conditions. Metallic $\mathrm{Pd}$ species appeared at $110{ }^{\circ} \mathrm{C}$. For the $\mathrm{Pd} / \mathrm{CZ}(\mathrm{NH})$ catalyst, oxidized Pd species, coexisting with metallic Pd species which showed the formation of top carbonyl (2089 $\left.\mathrm{cm}^{-1}\right)$ and bridge carbonyl $\left(1961 \mathrm{~cm}^{-1}\right)$ species, was present at the beginning of the reaction. The $\mathrm{Pd}^{0}$ species may be formed by the autoreduction of $\left[\mathrm{Pd}\left(\mathrm{NH}_{3}\right)_{4}\right]^{2+}$ ions after calcination at $500{ }^{\circ} \mathrm{C}$, in agreement with Wen et al. [50] who reported that $\mathrm{Pd}^{2+}$ ions with ammine ligands will auto-reduce followed by oxidation. As $\mathrm{Pd}^{0}$ species are the active sites for NO adsorption and dissociation, the appearance of $\mathrm{Pd}^{0}$ at a lower reaction temperature helps to promote the reaction of $\mathrm{CO}$ and NO $[30,49]$. On the other hand, compared with other two catalysts, the NCO peak appeared from a lower temperature (170 $\left.{ }^{\circ} \mathrm{C}\right)$ in $\mathrm{Pd} / \mathrm{CZ}(\mathrm{NH})$ catalyst. The results are in agreement with that the $\mathrm{Pd} / \mathrm{CZ}(\mathrm{NH})$ catalyst showed the best catalytic activity for $\mathrm{NO}_{x}$ reduction.
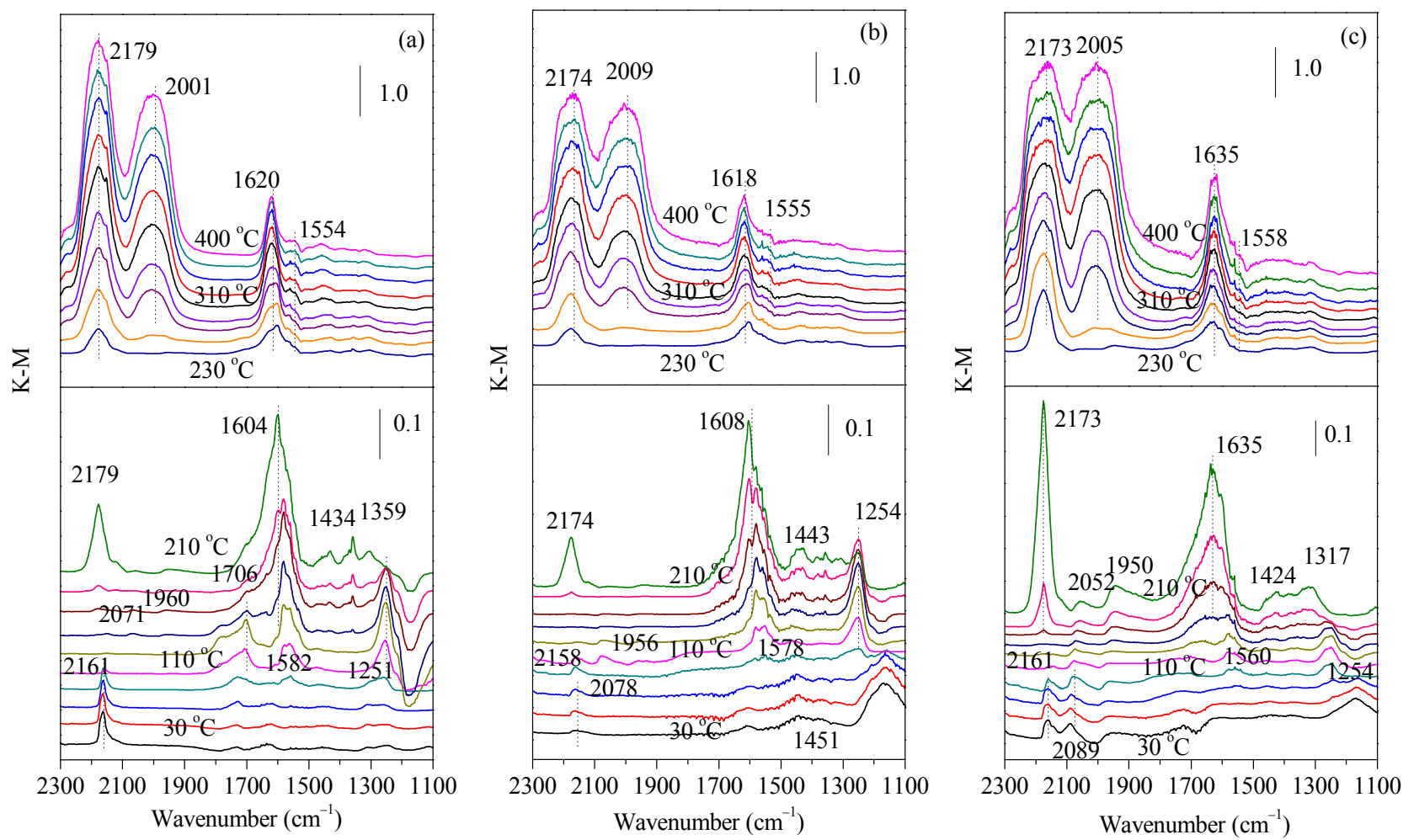

Fig. 7. DRIFTS spectra for fresh $\mathrm{Pd} / \mathrm{CZ}(\mathrm{Cl})(\mathrm{a}), \mathrm{Pd} / \mathrm{CZ}(\mathrm{NO})(\mathrm{b})$, and $\mathrm{Pd} / \mathrm{CZ}(\mathrm{NH})$ (c) catalysts under a stoichiometric $\mathrm{CO}+\mathrm{NO}_{x}+\mathrm{HC}+\mathrm{O}_{2}$ flow for reaction from 30 to $400{ }^{\circ} \mathrm{C}$ (from bottom to top). 
The bands in the region of $1100-1800 \mathrm{~cm}^{-1}$ were attributed to carbonate and nitrates/nitrites species adsorbed on the support. From Fig. 7(a), for the Pd/CZ(Cl) catalyst, the bands in the region of 1680-1460 and 1460-1200 $\mathrm{cm}^{-1}$, which showed an increase in intensity with increasing reaction temperature from $110^{\circ} \mathrm{C}$, were ascribed to nitrates in a variety of structures and configurations ranging from bridged, bidentate, and monodentate $\mathrm{NO}_{3}{ }^{-}$species adsorbed on $\mathrm{CZ}$ [51-53]. The nitrates species is formed by the oxidation of some bidentate nitrites by an activated $\mathrm{O}^{*}$ surface species and the reaction of an hydroxyl group on a $\mathrm{Ce}^{4+}$ cation with $\mathrm{NO}_{2}$, and the thermal stability of the nitrates adsorbed on zirconium sites is higher than that of nitrates adsorbed on Ce sites. The Pd/CZ(NO) and $\mathrm{Pd} / \mathrm{CZ}(\mathrm{NH})$ catalysts showed similar feature bands to the $\mathrm{Pd} / \mathrm{CZ}(\mathrm{Cl})$ catalyst. But compared with the $\mathrm{Pd} / \mathrm{CZ}(\mathrm{Cl})$ catalyst, the former showed stronger intensity for the chelated, bridged, and bidentate nitrites species adsorbed on $\mathrm{CZ}$ from $30{ }^{\circ} \mathrm{C}$, which was formed by the reaction of an hydroxyl group on a $\mathrm{Ce}^{4+} / \mathrm{Zr}^{4+}$ cation and an oxygen vacancy linked to a $\mathrm{Ce}^{3+}$ cation with $\mathrm{NO}$ or $\mathrm{NO}_{2}[48,49]$. These results suggested that for the $\mathrm{Pd} / \mathrm{CZ}(\mathrm{Cl})$ catalyst, the existence of $\mathrm{CeOCl}$ species inhibited the formation of hydroxyl groups and oxygen vacancy on the CZ surface $[38,54]$, in agreement with the oxygen vacancy results from Raman spectroscopy.

\section{Conclusions}

Catalytic behavior of $\mathrm{Pd} / \mathrm{Ce}_{0.67} \mathrm{Zr}_{0.33} \mathrm{O}_{2}$ catalysts prepared with different $\mathrm{Pd}$ precursors $\left(\mathrm{H}_{2} \mathrm{PdCl}_{4}, \mathrm{Pd}\left(\mathrm{NO}_{3}\right)_{2}\right.$ and $\left.\mathrm{Pd}\left(\mathrm{NH}_{3}\right)_{4}\left(\mathrm{NO}_{3}\right)_{2}\right)$ were investigated. The nature of the palladium precursor affected the nature and configuration of the noble metal particles, noble metal-support interaction and catalytic activity for $\mathrm{HC}, \mathrm{CO}$, and $\mathrm{NO}_{x}$ elimination. Among the fresh catalysts, the $\mathrm{Pd} / \mathrm{CZ}(\mathrm{NO})$ catalyst exhibited the best catalytic performance for $\mathrm{HC}$ and $\mathrm{CO}$ elimination as a result of a higher OSC, strong metal-support interaction improving electron transfer from $\mathrm{PdO}_{x}$ particles to the $\mathrm{CZ}$ support, and more small $\mathrm{Pd}_{n}$ clusters and active sites on the $\mathrm{Ce}_{0.67} \mathrm{Zr}_{0.33} \mathrm{O}_{2}$ surface. For the $\mathrm{Pd} / \mathrm{CZ}(\mathrm{NH})$ catalyst, the higher Pd dispersion and more bigger $\mathrm{Pd}_{n}$ clusters resulted in good performance for $\mathrm{NO}$ and $\mathrm{NO}_{2}$ elimination. The $\mathrm{Pd} / \mathrm{CZ}(\mathrm{Cl})$ catalyst exhibited low catalytic activity because of the relatively low $\mathrm{Pd}$ dispersion, weak $\mathrm{Pd}$-support interaction and a strong interaction between $\mathrm{Cl}$ and ceria leading to the formation of stable $\mathrm{CeOCl}$ species and inhibiting oxygen vacancy creation. However, after an aging treatment, it exhibited good thermal stability as a result of residual chlorine species being removed and the interaction between $\mathrm{PdO}_{x}$ and support being promoted. In situ DRIFTS also showed that the initial $\mathrm{PdO}_{x}$ species on the $\mathrm{Pd} / \mathrm{CZ}(\mathrm{NO})$ and $\mathrm{Pd} / \mathrm{CZ}(\mathrm{Cl})$ catalysts existed in the form of an oxidized state, while $\mathrm{Pd}$ metal and oxide species coexisted on $\mathrm{Pd} / \mathrm{CZ}(\mathrm{NH})$. Moreover, compared with the $\mathrm{Pd} / \mathrm{CZ}(\mathrm{Cl})$ catalyst, the initial oxidized PdO species on the Pd/CZ(NO) catalyst were more easily converted to $\mathrm{Pd}^{0}$ particles under reaction conditions, and the presence of the $\mathrm{Pd}^{0}$ particles promoted an increase in NO reduction activity.

\section{References}

[1] Rajasree R, Hoebink J H B J, Schouten J C. J Catal, 2004, 223: 36

[2] Mazumder V, Sun S. J Am Chem Soc, 2009, 131: 4588

[3] Yang M, Shen M Q, Wang J, Wen J, Zhao M W, Wang J, Wang W L. J Phys Chem C, 2009, 113: 12778

[4] Cui Y J, He S N, Fang R M, Shi Z H, Gong M C, Chen Y Q. Chin J Catal (崔亚娟, 何胜楠, 方瑞梅, 史忠华, 龚茂初, 陈耀强. 催化学报), 2012, 33: 1020

[5] Yang X, Yang L Y, Lin S Y, Zhou R X. Chin J Catal (阳雪, 杨林颜, 林 嗣煜, 周仁贤. 催化学报), 2014, 35: 1267

[6] Li G F, Wang Q Y, Zhao B, Shen M Q, Zhou R X. J Hazard Mater, 2011, 86: 911

[7] Kondratenko E V, Sakamoto Y, Okumura K, Shinjoh H. Appl Catal B, 2009, 89: 476

[8] Terribile D, Trovarelli A, Llorca J, de Leitenburg C, Dolcetti G. Catal Today, 1998, 43: 79

[9] Boaro M, de Leitenburg C, Dolcetti G, Trovarelli A. J Catal, 2000, 193: 338

[10] Xu X, Li Y, Gong Y T, Zhang P F, Li H R, Wang Y. J Am Chem Soc, 2012, 134: 16987

[11] Feng J T, Ma X Y, He Y F, Evans D G, Li D Q. Appl Catal A, 2012, 413-414: 10

\section{Graphical Abstract}

Chin. J. Catal., 2015, 36: 639-648 doi: 10.1016/S1872-2067(14)60264-3

\section{The effect of $\mathrm{Pd}$ precursor on $\mathrm{Pd} / \mathrm{Ce}_{0.67} \mathrm{Zr}_{0.33} \mathrm{O}_{2}$ catalysts for automotive emission control}

Siyu Lin, Linyan Yang, Xue Yang, Renxian Zhou*

Zhejiang University

$\mathrm{Pd} / \mathrm{CZ}(\mathrm{NO})$ and $\mathrm{Pd} / \mathrm{CZ}(\mathrm{NH})$ catalysts showed different behavior for $\mathrm{HC}, \mathrm{CO}$ and $\mathrm{NO}_{x}$ elimination due to the presence of small or big $\mathrm{Pd}_{n}$ clusters. A Pd/CZ(Cl) catalyst showed low catalytic activity due to poor Pd dispersion and trace amounts of $\mathrm{CeOCl}$ that inhibited oxygen vacancy creation.

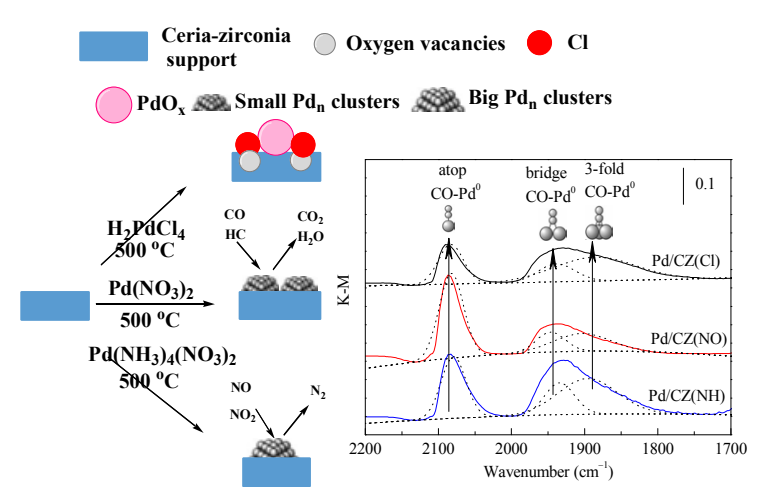


[12] Wang Q Y, Li G F, Zhao B, Zhou R X. Appl Catal B, 2010, 100: 516

[13] Wang Q Y, Li G F, Zhao B, Zhou R X. Fuel, 2011, 90: 3047

[14] Zhou R, Zhao B, Yue B H. Appl Surf Sci, 2008, 254: 4701

[15] Baylet A, Royer S, Marécot P, Tatibouët J M, Duprez D. Appl Catal B, 2008, 81: 88

[16] Panpranot J, Tangjitwattakorn 0, Praserthdam P, Goodwin J G. Appl Catal A, 2005, 292: 322

[17] Zhao B, Li G F, Ge C H, Wang Q Y, Zhou R X. Appl Catal B, 2010, 96: 338

[18] Fornasiero P, Dimonte R, Rao G R, Kaspar J, Meriani S, Trovarelli A, Graziani M. J Catal, 1995, 151: 168

[19] Suhonen S, Valden M, Hietikko M, Laitinen R, Savimakic A, Harkonen M. Appl Catal A, 2001, 218: 151

[20] Wang Q Y, Li G F, Zhao B, Zhou R X.J Hazard Mater, 2011, 189: 150

[21] Kang S B, Han S J, Nam S B, Nam I S, Cho B K, Kim C H, Oh S H. Chem Eng J, 2012, 207-208: 117

[22] Kang S B, Kwon H J, Nam I S, Song Y I, Oh S H. Ind Eng Chem Res, 2011, 50: 5499

[23] Takeguchi T, Manabe S, Kikuchi R, Eguchi K, Kanazawa T, Matsumoto S, Ueda W. Appl Catal A, 2005, 293: 91

[24] Kẹpiński L, Okal J.J Catal, 2000, 192: 48

[25] Fajardie F, Tempere J F, Manoli J M, Djega-Mariadassou G, Blanchard G. J Chem Soc, Faraday Trans, 1998, 94: 3727

[26] Kuno O. US Patent 7384888 B2. 2008

[27] Fernández-García M, Iglesias-Juez A, Martínez-Arias A, Hungría A B, Anderson J A, Conesa J C, Soria J.J Catal, 2004, 221: 594

[28] Monteiro R S, Dieguez L C, Schmal M. Catal Today, 2001, 65: 77

[29] Fernández-García M, Martínez-Arias A, Iglesias-Juez A, Hungría A B, Anderson J A, Conesa J C, Soria J. Appl Catal B, 2001, 31: 39

[30] Martínez-Arias A, Hungría A B, Fernández-García M, Iglesias-Juez A, Anderson J A, Conesa J C. J Catal, 2004, 221: 85

[31] Shen M Q Yang M, Wang J, Wen J, Zhao M W, Wang W L. J Phys Chem C, 2009, 113: 3212

[32] Royer S, Duprez D. ChemCatChem, 2011, 3: 24

[33] Kane M D, Roberts F S, Anderson S L. Faraday Discuss, 2013, 162: 323
[34] Shen M Q, Wei G X, Yang H M,Wang J, Wang X Q. Fuel, 2013, 103: 869

[35] Hinokuma S, Fujii H, Okamoto M, Ikeue K, Machida M. Chem Mater, 2010, 22: 6183

[36] Kobayashi T, Yamada T, Kayano K. Appl Catal B, 2001, 30: 287

[37] Barrabes N, Fottinger K, Llorca J, Dafinov A, Medina F, Sa J, Hardacre C, Rupprechter G. J Phys Chem C, 2010, 114: 17675

[38] Fallah J E, Boujana S, Dexpert H, Kiennemann A, Majerus J, Touret O, Villain F, Normand F L. J Phys Chem C, 1994, 98: 5522

[39] Li S P, Lu J Q, Fang P, Luo M F. J Power Sources, 2009, 193: 93

[40] Pu Z Y, Lu J Q, Luo M F, Xie Y L.J Phys Chem C, 2007, 111: 18695

[41] Luo M F, Yan Z L, Jin L Y.J Mol Catal A, 2006, 260: 157

[42] Reddy B M, Reddy G K, Katta L.J Mol Catal A, 2010, 319: 52

[43] Hickey N, Fornasiero P, Kašpar J, Gatica J M, Bernal S. J Catal, 2001, 200: 181

[44] Fan J, Wu X D, Wu X D, Liang Q, Ran R, Weng D. Appl Catal B, 2008, 81: 38

[45] He H, Dai H X, Ng L H, Wong K W, Au C T. J Catal, 2002, 206: 1

[46] Ferrer V, Moronta A, Sánchez J, Solano R, Bernal S, Finol D. Catal Today, 2005, 107-108: 487

[47] Domingos D, Rodrigues L M T S, Frety R, Brandao S T. Combust Sci Technol, 2014, 186: 518

[48] Lin W, Zhu Y X, Wu N Z, Xie Y C, Murwani I, Kemnitz E. Appl Catal $B, 2004,50: 59$

[49] Martínez-Arias A, Fernández-García M, Iglesias-Juez A, Hungría A B, Anderson J A, Conesa J C, Soria J. Appl Catal B, 2001, 31: 51

[50] Wen B, Jia J, Sachtler W M H.J Phys Chem B, 2002, 106: 7520

[51] Martínez-Arias A, Fernández-García M, Hungría A B, Iglesias-Juez A, Duncan K, Smith R, Anderson J A, Conesa J C, Soria J. J Catal, 2001, 204: 238

[52] Atribak I, Azambre B, Bueno López A, García-García A. Appl Catal $B, 2009,92: 126$

[53] Azambre B, Atribak I, Bueno-Lopez A, Garcia-Garcia A.J Phys Chem C, 2010, 114: 13300

[54] Huang Y Q, Wang A Q, Li L, Wang X D, Zhang T. Catal Commun, 2010, 11: 1090

\title{
钯前驱体对汽车尾气处理Pd/ $\mathrm{Ce}_{0.67} \mathrm{Zr}_{0.33} \mathrm{O}_{2}$ 催化剂催化性能的影响
}

\author{
林嗣煜, 杨林颜, 阳雪, 周仁贤* \\ 浙江大学化学系催化研究所, 浙江杭州 310028
}

\begin{abstract}
摘要: 分别以 $\mathrm{Pd}\left(\mathrm{NO}_{3}\right)_{2}, \mathrm{Pd}\left(\mathrm{NH}_{3}\right)_{4}\left(\mathrm{NO}_{3}\right)_{2}$ 和 $\mathrm{H}_{2} \mathrm{PdCl}_{4}$ 为钯前驱体制备了 $\mathrm{Pd} / \mathrm{Ce}_{0.67} \mathrm{Zr}_{0.33} \mathrm{O}_{2}(\mathrm{CZ})$ 催化剂. 以硝酸钯为钯前驱体制得的 $\mathrm{Pd} / \mathrm{CZ}(\mathrm{NO})$ 催化剂具有较高的储氧量, 存在较多的小的钯簇, 其钯与载体间相互作用较强, 因此在三种新鲜催化剂中对 $\mathrm{HC}$ 和 $\mathrm{CO}$ 的 消除表现出了最好的催化活性. 以硝酸四氨钯为钯前驱体制得的 $\mathrm{Pd} / \mathrm{CZ}(\mathrm{NH})$ 催化剂具有较高的钯分散度, 存在较多的大的钯簇, 同时存在金属态和氧化态的钯, 从而对 $\mathrm{NO}_{\text {和 }} \mathrm{NO}_{2}$ 的消除表现出了较好的催化活性. 以氯钯酸为钯前驱体制得的 $\mathrm{Pd} / \mathrm{CZ}(\mathrm{Cl})$ 催化剂 由于钯分散度较小, 钯与载体间作用较弱, 存在的 $\mathrm{CeOCl}$ 抑制了氧空穴的生成, 因此对各种反应物的催化活性都较低. 但 $\mathrm{Pd} / \mathrm{CZ}(\mathrm{Cl})$ 催化剂表现出了较好的热稳定性, 这是由于老化处理消除了残余的氯物种并且促进了钯与载体间的作用.
\end{abstract}

关键词: 钯前驱体; 三效催化剂; 金属载体间相互作用; 起燃催化活性

收稿日期: 2014-10-29. 接受日期: 2014-12-12. 出版日期: 2015-04-20.

*通讯联系人. 电话: (0571)88273290; 传真: (0571)88273283; 电子信箱: zhourenxian@zju.edu.cn

基金来源：国家高技术研究发展计划(863计划, 2011AA03A406); 浙江省重点科技创新团队计划(2009R50020).

本文的英文电子版由Elsevier出版社在ScienceDirect上出版(http://www.sciencedirect.com/science/journal/18722067). 